地第 2 輯

第 45 巻（1992） 97-105頁

\title{
地震発生に関連した前兆的地殼変動
}

\author{
名古屋大学理学部地震火山観測地域センター* 山 内 常 生

\section{Precursory Ground Strains and Tilts Related to Earthquake Occurrence}

\author{
Tsuneo YAMAUCHI \\ Research Center for Seismology and Volcanology, School of Science, Nagoya University, \\ Furo-cho, Chikusa-ku, Nagoya 464-01, Japan
}

(Received September 2, 1991; Accepted November 5, 1991)

\begin{abstract}
Crustal movement observations for earthquake prediction research in and near fractured zones have attracted the attention of many researchers in recent years. Data obtained from fractured zones sometimes shows abnormal variations in relation to earthquake occurrence. Tectonic stress over a wide area tends to be concentrated in and near the fractured zone and anomalies were observed at sites situated far from the focal region. Tectonic stress over a wide area may provide more useful data than information from tectonic stress in a limited focal region. Data obtained at the same sites showed that anomalies preceding events sometimes resemble each other. It seemed that tectonic stress may show similar patterns in directly influencing such activities. One typical example of this was seen in data obtained at the Mikawa Crustal Movement Observatory (Aichi, Japan). Anomalies seemed to be related to the occurrence of nearby earthquakes within a specified region around the observatory.
\end{abstract}

Key words: Precursor, Earthquake prediction, Fractured zone, Abnormal variation, Elastic aftereffect.

\section{§1.はじめに}

伸縮計や傾斜計は震源域あるいはその周辺において歪 が蓄積する過程を直接測定できるため地震予知にとって 重要な役割をになっている. 地震予知研究計画が発足し てから四半世紀が経過し, 計測技術の向上とともに観測 地点の増加によって, 前兆的地殻变動が複数の地点でな されるまでになった[MIURA et al. (1990)]．今までに蓄 積した資料 [山内 (1985)] から判断すると, 破砕帯むし くはその近傍にある観測点の方が通常の観測点よりも地 震の前兆的变化を観測しやすい，ここでは震源域とその 周辺に作用する広域の地款応力に着目して, 地震に関連 した前兆的現象の発生するメカニズムについて考察して みる.

\section{§2. 地震前後における異常な地殻変動}

Fig. 1 は 1983 年の日本海中部地震 $(M=7.7)$ 前後に

\footnotetext{
* ₹464-01 名古屋市千種区不老町
}

おいて東北大学理学部の地殻活動総合観測線で観測され た地款変動の記録と潮位計の記録を示したものである [MIURA et al. (1990)]. この地震の前には男鹿と仁別観 測点で同時に前兆的地殼変動が観測された。この変化に やや先行して男鹿と深浦の潮位計にも変動か記録されて いる. 地壳変動の観測網は以前よりも充実してきてお り, 今後は, この例のように異常変化が複数の地点で観 測される機会が増えるであろう. MiURA et al. (1990) は 仁別で観測された地震の数年前からの伸縮変化を説明す るモデルとして断層のプレスリップを考えた。

山崎断層付近で発生した 1984 年 5 月の地震 $(M=$ 5.6) の場合は, 京都大学防災研究所の山崎断屏観測室と 京都大学理学部の生野観測室で前兆と思われる変化が観 測された. WATANABE (1991) の報告によると山崎断層 観測室では地震の発生の 7 ケ月ほど前から伸縮計の記 録が急変した (Fig. 2). 藤森・他 (1984) は, 生野観測室 において疑灰岩と流紋岩の接触面（もしくは断首）をま たいで設置してある伸縮計で地震の発生の 7 日ほど前 


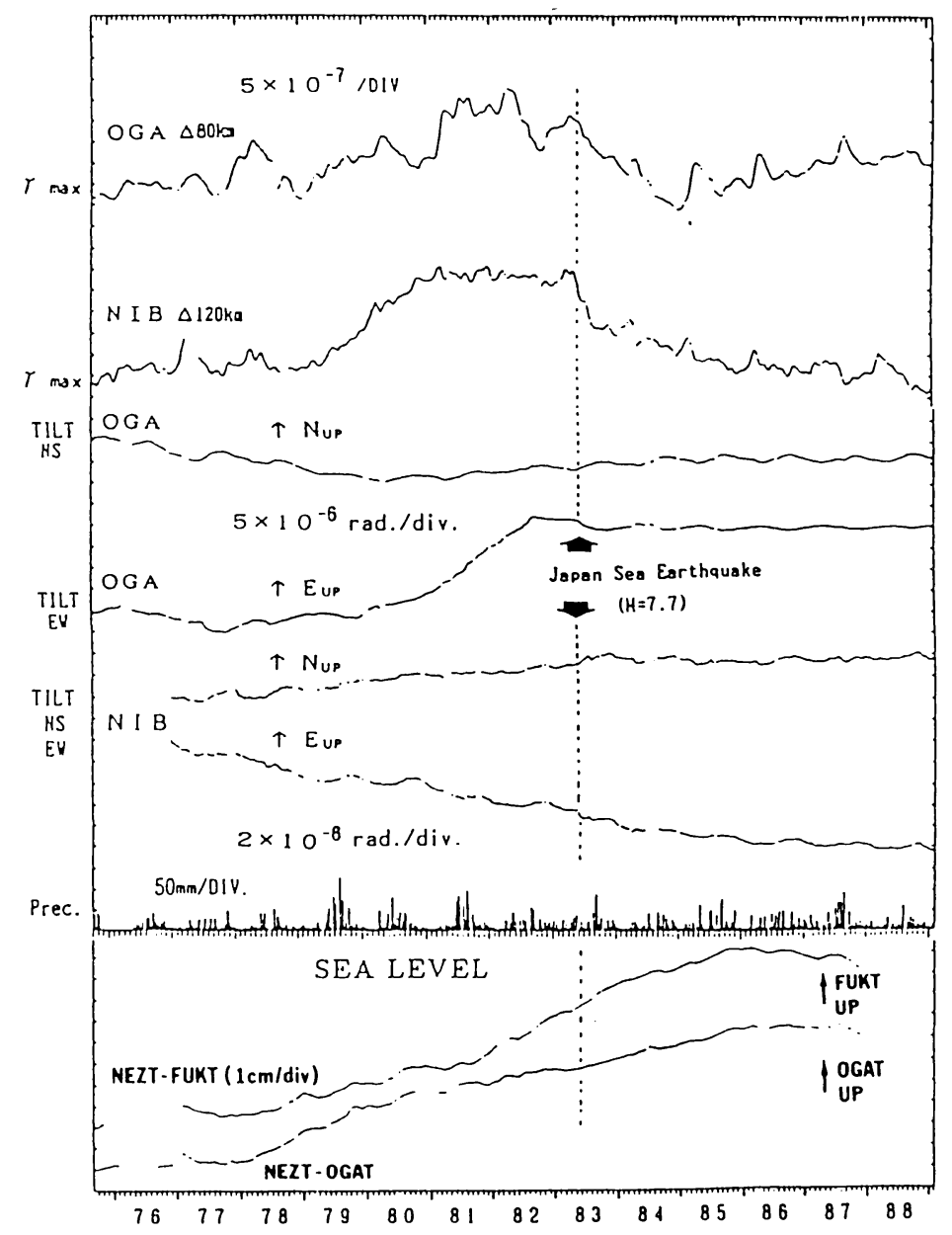

Fig. 1. Crustal deformation data before and after the 1983 Japan Sea earthquake. Maximum shear strain, NS and EW tilt components at OGA and NIB station, daily precipitation, and difference in monthly mean sea level between FUKT and NEZT and between OGAT and NEZT (filtered by 24 months running mean) (after MiURa et al., 1990).

から異常な変動を観測したと報告している (Fig. 3). 同 じ地震でありながら山崎断層観測室と生野観測室とでは 前兆的変動の現れる様子が違っていた.

三河地殼変動観測所の場合は観測所の近傍で地震が発 生するとき，その前後で降雨に対する地殼歪レスポンス が異常になる，通常は降雨に対する地款歪レスポンスは 均一で, 方位が同じであればどの検出部の変化も似てい る.また，この地款歪レスポンスは流出解析で用いられ るタンクモデルを適用するとよく近似できる［山内 (1981)]. ところが, 観測所の近傍で地震が発生する場合 には観測される変化と予測値は一致せず, 観測坑む不均 一な変動をする. Fig. 4 にその一例を示す. 1976 年 10 月 12 日の地震 $(M=3.2)$ の前の伸縮計の動きはモデル により推定した変動と違っている. さらに, 同じ伸縮計 の $20 \mathrm{~m}$ と $40 \mathrm{~m}$ の位置に取り付けた検出部の差
NE40-NE20 は直線ではなく, 降雨に対する地殼歪レス ポンスが不均一であったことが分かる．わずかではある が 11 月 25 日と 28 日の地震の前にも異常が見られる. 地震の発生に関連した応力の影響で観測坑近傍の岩盤中 の透水係数が変わり, 降雨に対する地款の応答が異常に なると思われる. 詳細については Y AMAUCHI (1987)を 参照されたい。

\section{§ 3. 観測された前兆的地殻变動の性㑭}

日本国内において地震の前兆と見なされるとして報告 された伸縮変化や傾斜変化をまとめて Table 1 に示し た. 対象とした地震は 1973 年 1 月以降に発生したもの である. 破砕帯近傍における観測例は通常の観測点の場 合よりも多いことが Table 1 から分かる. 三河地款変動 観測所の場合は破砕帯をはさむ部分で異常が観測される 


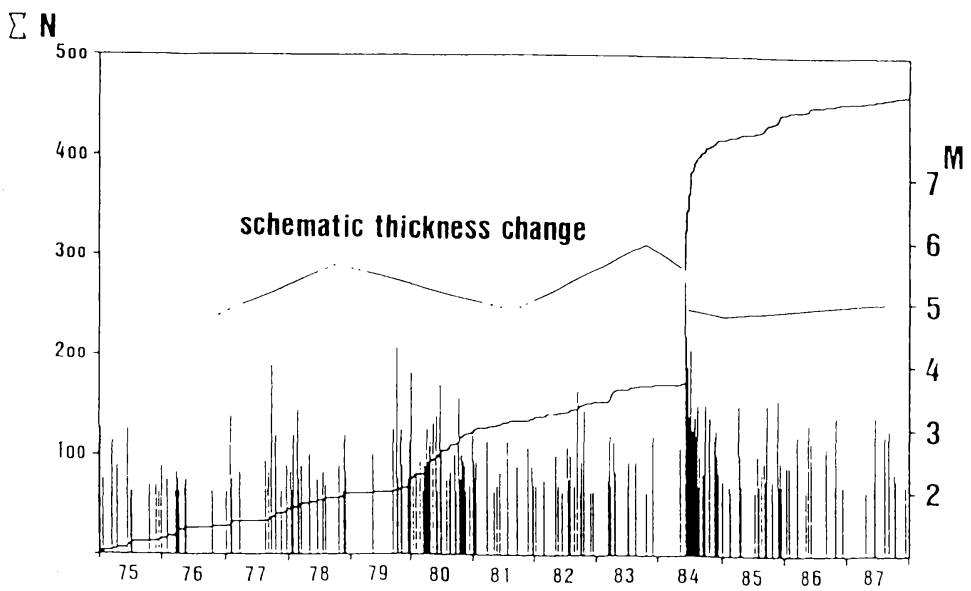

Fig. 2. Time series of earthquakes and their accumulated number in the surrounding area.

The schematic diagram of the strain change normal to the Yasutomi fault zone (after W ATANABE, 1991).

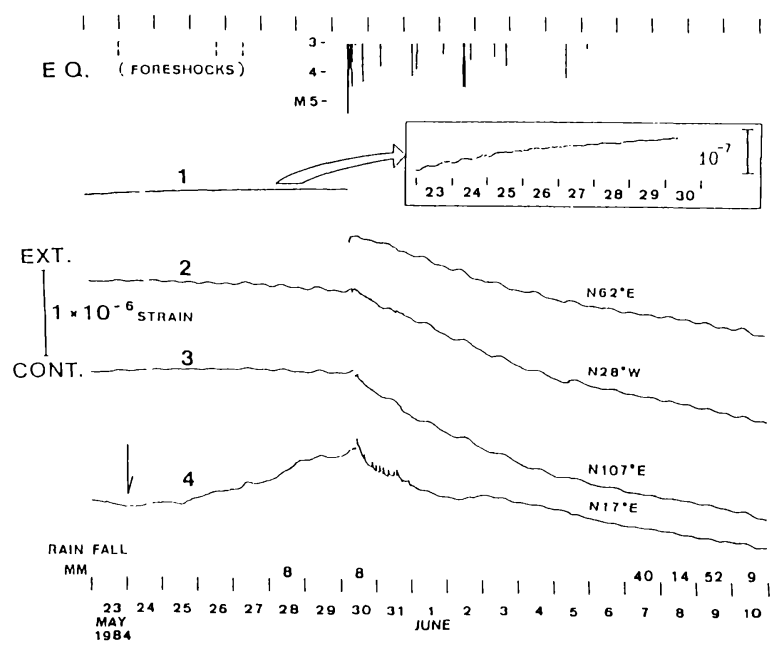

IKUNO Extensometer

Fig. 3. Strain changes observed at Ikuno station before and after an earthquake of $M=5.6$ occurred at the epicentral distance $31 \mathrm{~km}$ (after FuJimori et al., 1984).

ことが多い，論文に記述されたデータによると，異常変 動の大きさ, 現れ方, 継続時間等は個々に違っており共 通する性質はほとんどない。しかし，多くの観測地点で pre-seismic な地款変動が co-seismic あるいは postseismic な地款変動と同等かもしくはそれよりも大き い.

Fig. 5 は三河地壳変動観測所付近で 1974 年 1 月から 1984 年 12 月までの 11 年間に発生した地震 $(M=\geqq 3.5$ の震央をプロットしたあのである. 範囲は東経 $136^{\circ} 30^{\prime}$ から $138^{\circ} 20^{\prime}$, 北緯 $34^{\circ} 20^{\prime}$ から $35^{\circ} 30^{\prime}$ である. 使用し た資料は気象庁の地震月報で震源の深さは $60 \mathrm{~km}$ より あ浅い、なお，図の下方にあたる北緯 $34^{\circ} 20^{\prime}$ から $34^{\circ}$
30 の間にはこの期間中に地震は発生しなかった，異常 変化を伴った地震はの，異常変化を伴わなかった地震は ○, 異常の有無を判断できなかった地震は $\triangle て ゙$ でした。 異常の有無を判断できなかった場合は降雨がないか降雨 があっても降雨量が少なくてその影響が観測されなかっ たときである. Fig. 5 から分かるように異常な変化を 伴った地震の震源は観測所の周りの破線で囲んだブロッ クの中に限られている. 山崎・大井田 (1985) は微小地 震の分布からフイリッピン海プレートの北端部が, Fig. 6 で示すように 3 個のスラブに分かれていることを見出 した. Fig. 6 の中央部の東海スラブの形状は Fig. 5 で示 したブロックの形状とほぼ一致する. 


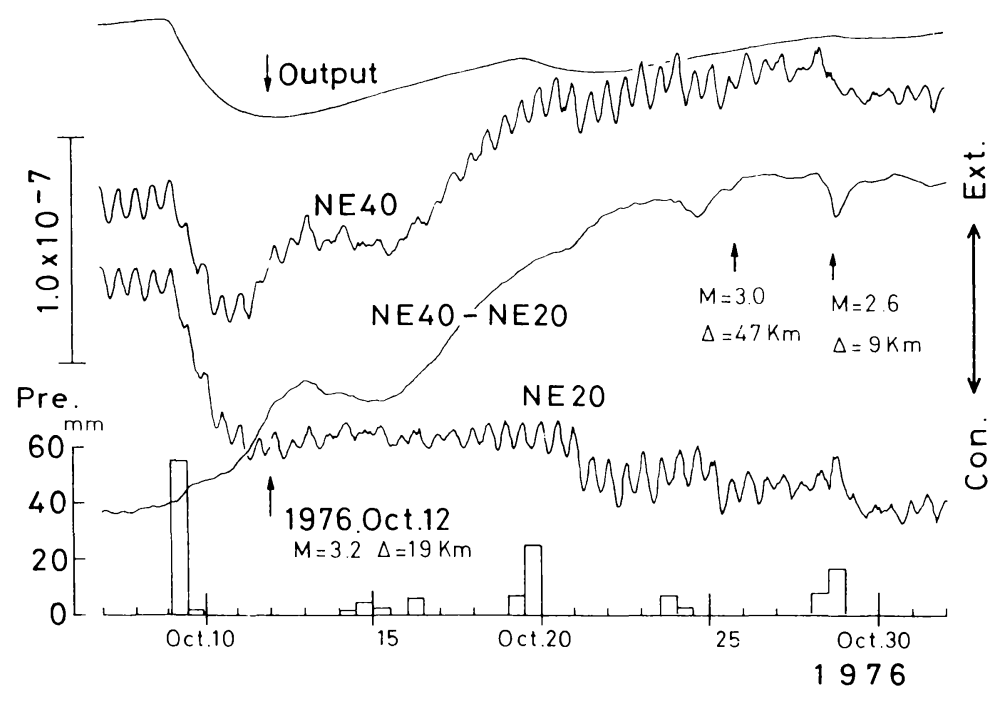

Fig. 4. An example of abnormal strain responses of $N 19^{\circ} \mathrm{E}$ components to rainfalls before and after the occurrences of earthquake.

NE40-NE20 indicates the strain difference of the sensor NE40 and NE20. Upper curve shows output of a tank model.

Table 1. List of earthquakes preceded by precursors.

\begin{tabular}{|c|c|c|c|c|c|}
\hline Date & Location & $M$ & Depth & Distance & Reference \\
\hline June 17,1973 & Off Nemuro peninsula & 7.4 & 40 & 250 & KASAKARA $(1976)$ \\
\hline Nov. 25, 1973 & Central Wakayama pref. & 5.9 & 60 & 43 & Ozawa (1978) \\
\hline Feb. 10,1974 & Western Aichi pref. & 5.3 & 40 & 60 & *YAMAUCHI (1987) \\
\hline Feb. 24,1974 & Western Shizuoka pref. & 4.6 & 0 & 37 & *YAMAUCHI (1987) \\
\hline Mar. 14,1975 & Aichi-Gifu border & 5.3 & 50 & 85 & *YAMAUCHI (1987) \\
\hline Nov. 12,1975 & South coast of Aichi pref. & 4.2 & 29 & 9 & *YAMAUCHI (1987) \\
\hline May $\quad 9,1976$ & South off Shizuoka pref. & 4.1 & 40 & 19 & *YAMAUCHI (1987) \\
\hline June 6,1976 & Nagano-Aichi border & 4.0 & 10 & 55 & *YAMAUCHI (1987) \\
\hline Nov. 15,1976 & Eastern Aichi pref. & 3.8 & 50 & 40 & *YAMAUCHI (1987) \\
\hline Dec. 27,1976 & Near Hamamatsu & 3.5 & 40 & 27 & *YAMAUCHI (1987) \\
\hline Apr. 30,1977 & Western Shizuoka pref. & 4.2 & 20 & 30 & *YAMAUCHI (1987) \\
\hline July 19,1977 & Southern Aichi pref. & 3.5 & 40 & 26 & *YAMAUCHI (1987) \\
\hline Aug. $\quad 6,1977$ & Western Aichi pref. & 4.3 & 50 & 73 & *YaMAUCHI (1987) \\
\hline May 26,1979 & Aichi-Gifu border & 3.7 & 40 & 21 & *YAMAUCHI (1987) \\
\hline Mar. $\quad 4,1980$ & Southern Chubu & 3.5 & 40 & 16 & *YAMAUCHI (1987) \\
\hline June 29,1980 & Izu peninsula region & 6.7 & 10 & 14 & *Y ANAGISAW A (1980) \\
\hline Aug. 18, 1981 & Southern Chubu & 5.0 & 50 & 59 & *YAMAUCHI $(1987)$ \\
\hline June 21,1982 & South coast of Chubu & 4.9 & 40 & 39 & *Y AMAUCHI (1987) \\
\hline Mar. 16,1983 & South coast of Chubu & 5.7 & 40 & 14 & *YAMAUCHI (1987) \\
\hline Mar. 26, 1983 & South coast of Chubu & 3.5 & 42 & 25 & *YAMAUCHI (1987) \\
\hline Aug. 8,1983 & Kanto-Chubu border & 6.0 & 22 & 31 & *SATo et al. (1984) \\
\hline \multirow[t]{2}{*}{ May 26,1983} & W off $\mathrm{N}$ Tohoku & 7.7 & 14 & 120 & $\begin{array}{l}\text { Miura et al. (1990) } \\
\text { (Nibetsu) }\end{array}$ \\
\hline & & 7.7 & 14 & 80 & $\begin{array}{l}\text { Miura et al. (1990) } \\
\text { (Oga) }\end{array}$ \\
\hline May 30,1984 & Northern Kinki & 5.6 & 17 & 31 & *FuJimoRi et al. (1984) \\
\hline Mar. 18,1987 & Hyuganada region & 6.6 & 48 & 62 & Ону а $(1988)$ \\
\hline
\end{tabular}

* Data observed at a site in and near a fractured zone. 


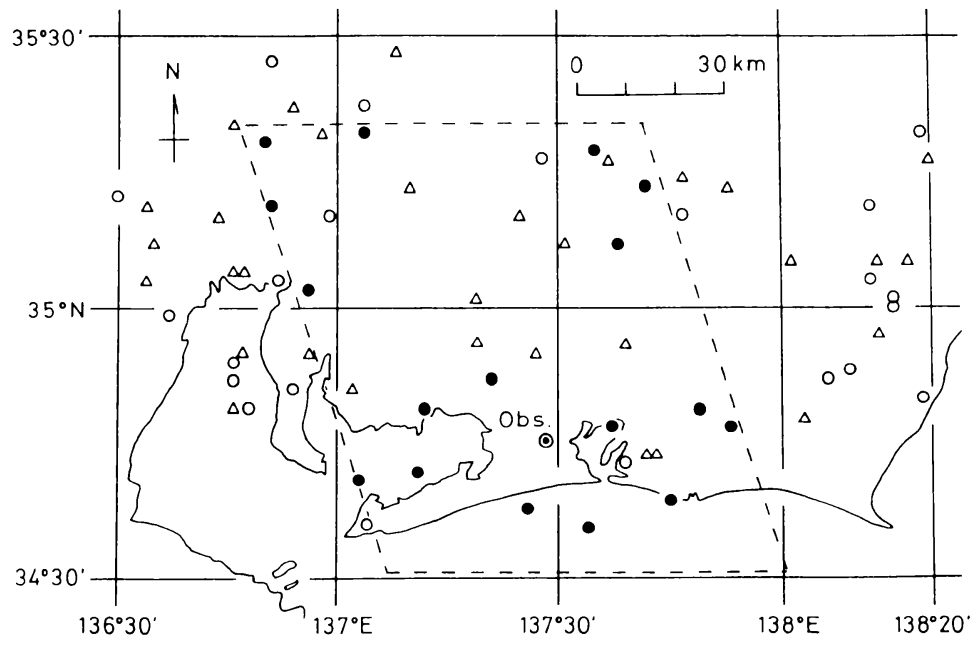

Fig. 5. Epicenters located by JMA for $M \geqq 3.5$ earthquakes near the observatory in the period from January 1974 to December 1984.

Closed circles, event preceded by precursors; open circles, event not preceded by any precursor; triangle, event at no rainfall or at precipitation of less than $15 \mathrm{~mm}$.

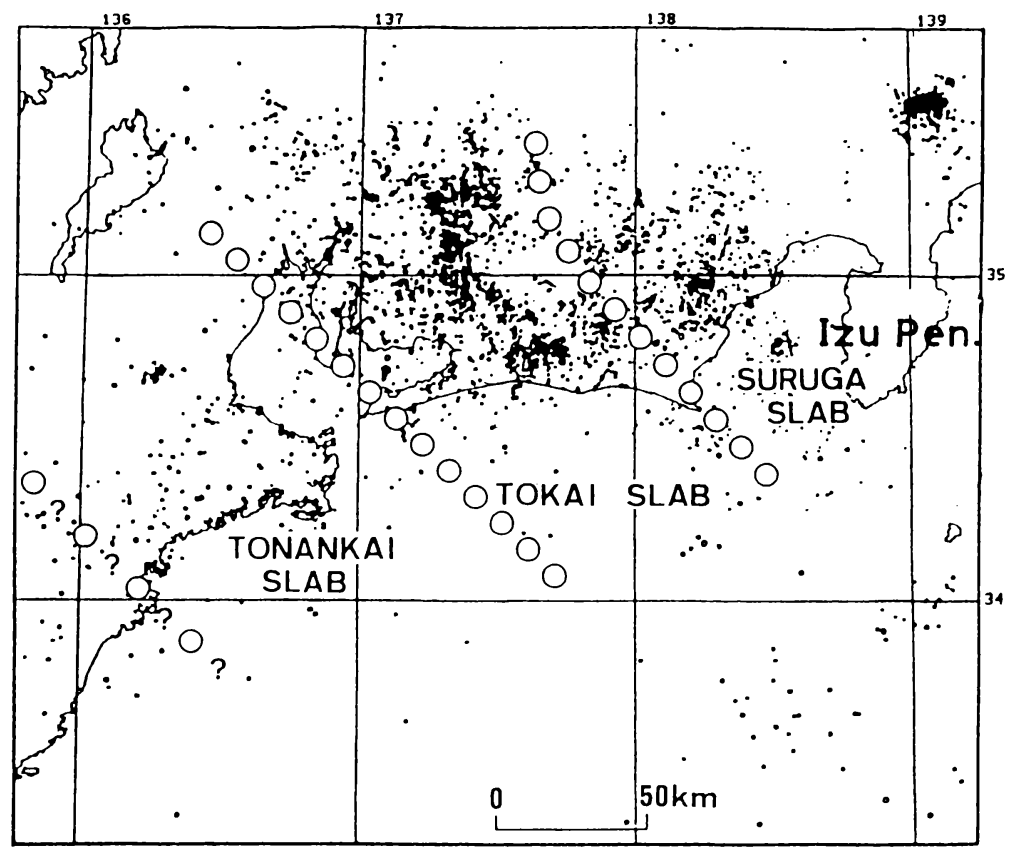

Fig. 6. Distribution of earthquakes between $20 \mathrm{~km}$ to $80 \mathrm{~km}$ in depth for the period from April 1978 through March 1984.

Boundaries of descending slabs are shown by open circles (after YAMAZAKI and OoIDA, 1985).

\section{§4. 震源域およひその周辺における地殻変動}

震源域で生じた地款変動の影響は遠方にゆくほど減少 する. 断層モデルでは, 震源からの距離 $R$ の 3 乗に逆比 例するが，地表近くにおける観測結果からは $R$ の 2.4 乗 に逆比例することが知られている [竹本・高田 (1969),
田中 (1972)].ここでは, その影響が R の 2.5 乗に逆比 例すると考えて, 観測值から震源領域の半径 $r$ の地点で の歪の大きさを逆算してみた。 その結果を Table 2 に示 す。この計算に用いた半径 $r$ は檀原 (1966) が水準測量 の結果から求めた地款の上下変動域の半径 
Table 2. List of earthquakes and estimated crustal deformations at focal regions.

\begin{tabular}{|c|c|c|c|}
\hline Date & Location & $M$ & Crustal deformation $\left(\times 10^{-5}\right)$ \\
\hline June 17,1973 & Off Nemuro peninnsula & 7.4 & 4.0 \\
\hline May 26,1983 & W off N Tohoku (Nibetsu) & 7.7 & 2.2 (Nibetsu) \\
\hline May 26,1983 & W off N Tohoku (Oga) & 7.7 & 0.4 (Oga) \\
\hline Mar. 14,1975 & Aichi-Gifu border & 5.3 & $* 10$ \\
\hline Nov. 12,1975 & South coast of Aichi pref. & 4.2 & * 15 \\
\hline Nov. 15,1976 & Eastern Aichi pref. & 3.8 & $* 600$ \\
\hline Mar. $\quad 4,1980$ & South coast of Chubu & 3.5 & $* 100$ \\
\hline June 29,1980 & East off Izu peninsula & 6.7 & * 2.5 \\
\hline June 21,1982 & South coast of Chubu & 4.9 & * 17 \\
\hline Aug. $\quad 8,1983$ & Kanto-Chubu border & 6.0 & $* 2.0$ \\
\hline May 30,1984 & Northern Kinki & 5.6 & $* 8.0$ \\
\hline
\end{tabular}

* Data observed at the site in and near the fractured zone.

$$
\log r^{3}=1.53 M+8.18
$$

である. $M$ は地震のマグニチュードである. Table 2 の 上部の 3 例によると, 地震の発生の前に震源域で生じる と推定される地壳変動は $1-5 \times 10^{-5}$ 程度である.これ らの前兆的な地殻変動の大きさは地震時の変動と同じく らいで, 震源域での変化としては大きすぎる. 資料とし て破砕帯近傍における観測データを用いると, 計算結果 はさらに大きくなる. したがって, 異常変動の出現する 原因は, 震源での応力変化によるものではなく別のメカ ニズムによると考えるべきである. 以下では, 先に述べ た東海スラブを例にして前兆現象の観測されるメカニズ
ムについて考察してみる.

東海スラブにはフイリッピン海プレートの沈み込みに 伴う広域の応力が作用している. スラブを水平方向の応 力の作用を受けているブロックとみなし，その中で地震 が発生する場合を考える. 単純化してブロックの変形の 状態を Fig. 7 で示すように A から E に分ける. このブ ロックには多くの断層とか破砕帯が存在するものとす る. ママで示した地点が観測点で, 近くに破砕帯があると する.
A；ブロックに作用している広域の応力が変化し，ブ ロックの変形が始まる.
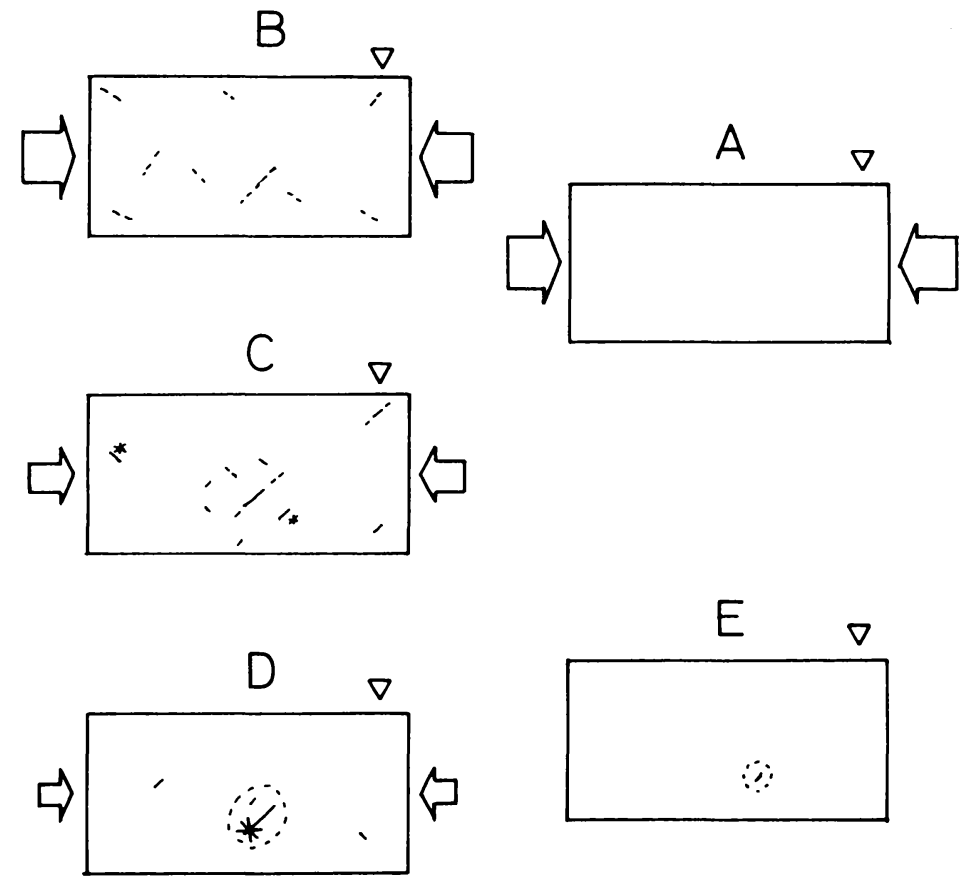

Fig. 7. Diagram showing the deformation stages of the Tokai slab. 
B；断層とか破砕帯に応力の集中が始まり，応力の集 中で生じたブロックの歪が，流動（破砕帯のすべ り）や小破壊（微小地震）によって解放され始め る.

$\mathrm{C}$; 時間の経過とともに歪の解放と変形がすすみ, ブ ロックの安定化が始まるが, 歪が解放できない場 所が点在するようになる.

D；ブロック全体が安定化するのに呼応して特定の領 域に応力が集中し, 歪が極限まで蓄積し地震とな る.

$\mathrm{E}$ ；震源域で余震等によって歪が解放されるとともに ブロック全体で応力の再配分が進行する.

いままでに観測された異常変化の多くは，ブロックが Cの状態にあり，震源域が形成される前後に出現したの ではなかろうか. ブロックがこのような状態のときは震 源域の位置には関係なく, 特定の破砕帯の近傍では地款 変動が生じやすくなり近くに観測点があれば異常変化が 観測されるであろう.ブロックが C の状態のときに生じ た破砕帯近傍の異常な変化はすぐに消隇してしまうこと ああろうし，ブロックが D の状態になるまで（すなわ ち, 地震の発生まで）持続することああろう. 同じ地震 に伴う地殼変動であってあ観測地点の条件によってその 現れ方が違い, 先に示した山崎断層付近の地震に関連し た地款変動のように，異なった変化が観測されるのであ ろう。通常の観測点であってもその観測点がたまたま震 源域の近くにあるときには MIURA et al. (1990) のよう に断層のプレスリップで説明できるような前兆的な変化 が出現する.このように考えるといままでに観測された
地震前の異常な地殻変動をそれほど矛盾なく説明でき る.

破砕帯等で異常が観測された場合，その異常は将来発 生する地震の前兆ではなく，広域の応力に対してブロッ クが変形したために生じた現象であると考えるべきであ る.ブロックが D の状態に移る頃にはブロック全体で歪 の解放はおおむね終わっており，震源域にのみ歪が集中 しその領域で地震が発生すると思われる.ブロックに作 用する応力が小さい場合にはブロックの変形は B P C の状態で終わってしまうこともあろう．このようなとき は微小地震あるいは小地震しか発生しないであろう.

Fig. 8 は三河地款変動観測所で観測した地震前後の $\mathrm{N} 26^{\circ} \mathrm{W}$ 方向の伸縮変化である. 東海スラブの中で発生 した地震に伴う余効変化の場合は 3 方向の伸縮計のう ちで $\mathrm{N} 26^{\circ} \mathrm{W}$ 方向の伸縮計の収縮がつねに大きい。この 方向は東海スラブの進行する方向とおおむね一致する. 地震の発生の度にスラブ内での応力の再配分により, ス ラブ全体がわずかであるが沈降するのであろう。Table 3 は東海スラブの中で発生した地震に伴った strainstep と余効的な変動との比をとったものである. その大 きさは 10 前後でほぼ一定している. 地震のマグニ チュードが大きければ観測される strain-step は大きく なるが，それに対応してスラブの沈降する割合む大きく なると推測される.このモデルによればブロックが Cの 状態にあり，かつ，ブロックの中央付近に将来地震が発 生する領域が生じるときには，地款活動に関する種々の 現象がその領域を取り囲むように発生し，ドーナッ現象 が生じる.

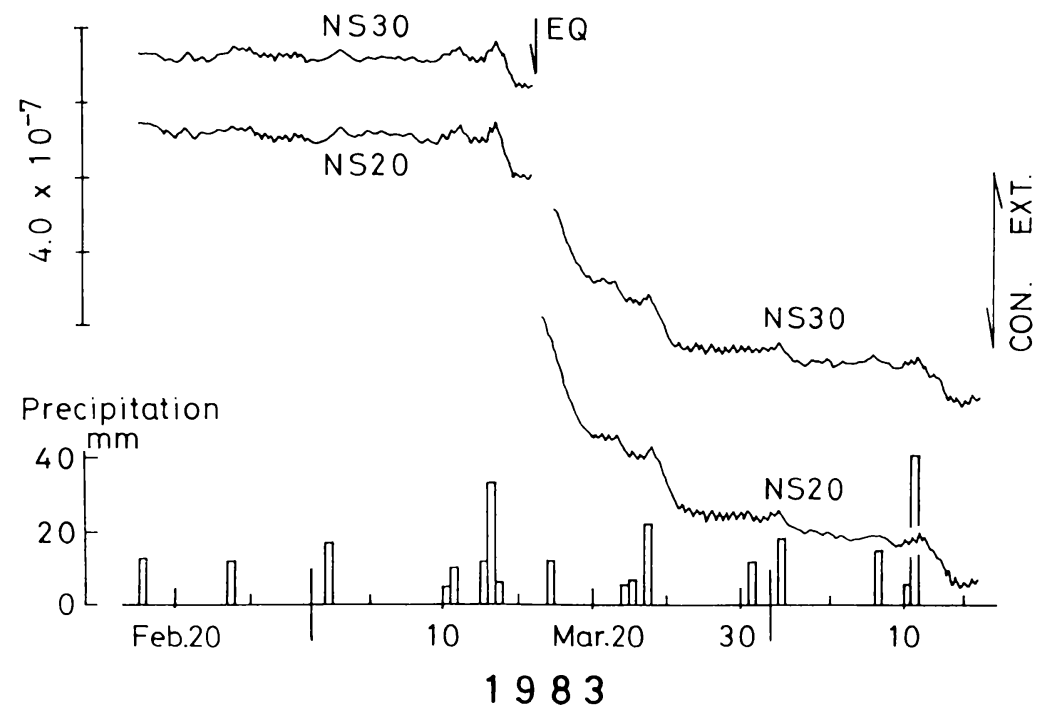

Fig. 8. An example of the elastic after-effect observed with extensometer (NS component) in connection with the occurrence of nearby earthquake. 
Table 3. The ratio of observed elastic after-effect to strain step.

\begin{tabular}{ccccc}
\hline \hline Date & $M$ & $\begin{array}{c}\text { Elastic } \\
\text { after-effect } \\
\left(10^{-8}\right)\end{array}$ & $\begin{array}{c}\text { Strain step } \\
\left(10^{-8}\right)\end{array}$ & Ratio \\
\hline Feb. 10, 1974 & 5.3 & 4.0 & 0.25 & 16 \\
Mar. 15, 1975 & 5.3 & 7.5 & 0.25 & 30 \\
Nov. 12, 1975 & 4.2 & 2.5 & 0.5 & 5.0 \\
May 9, 1976 & 4.1 & 1.0 & 0.13 & 7.7 \\
Apr. 30, 1977 & 4.2 & 2.0 & 0.1 & 30 \\
Mar. 4, 1980 & 3.5 & 6.0 & 1.3 & 6.3 \\
Aug. 18, 1981 & 5.0 & 8.0 & 14 & 3.5 \\
Mar. 16, 1983 & 5.7 & 50 & & \\
\hline
\end{tabular}
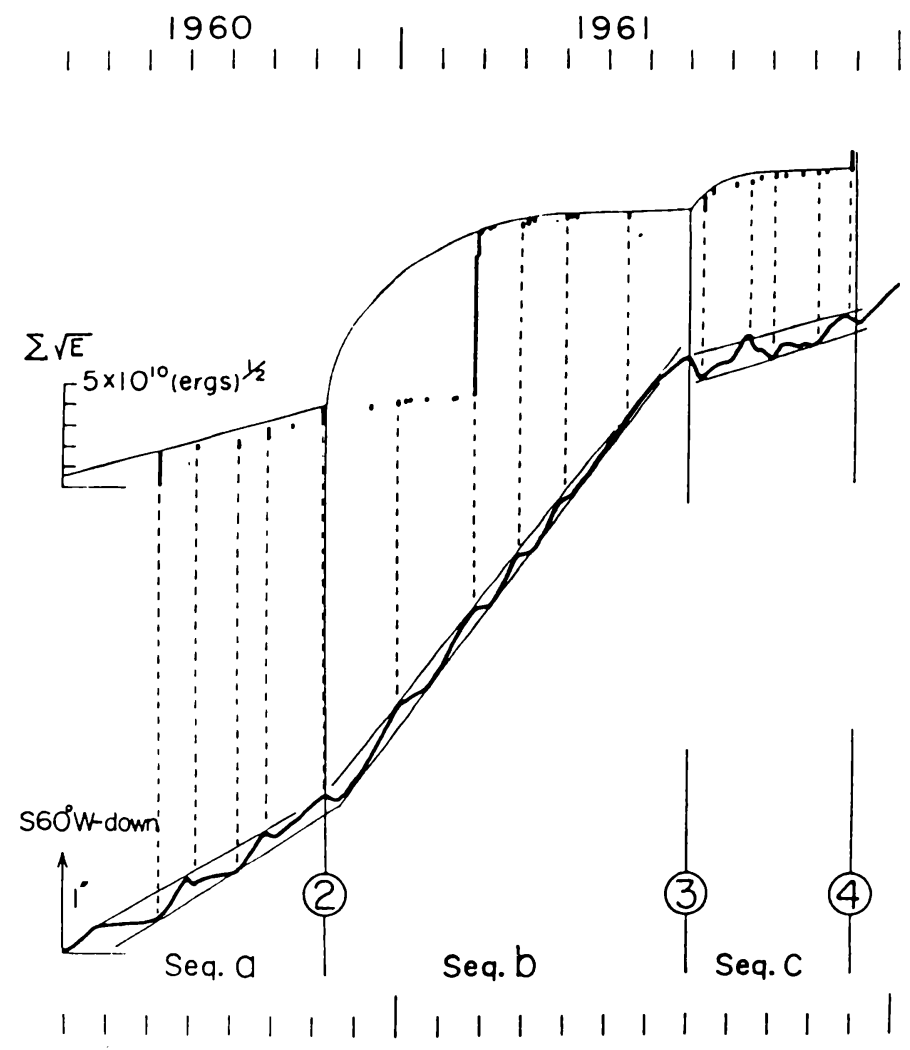

Fig. 9. Tilt variation in the direction of horizontal displacement near Makimine and the state of strain release caused by the crustal earthquake originated in the Hyuganada (after TANAKA, 1965).

ここでは, 東海スラブという特定の領域での地震の発 生と地款変動との関係を論じたが, 本稿で示した考え方 は他の地域でも成り立つと思われる. 田中(1965) は広 域的な応力に着目し, 西日本の各地で傾斜計による一連 の異常変化と地震活動との関係を調べた. そして, 観测 された異常变動を 3 段階に分けその変化が出現するメ カニズムについて論じている. Fig. 9 は九州の檱峰にお ける傾斜変動と日向灘の地震活動との関係を示したもの
である. Fig. 9 より地震の発生と記録の変化とがよく対 応していることが分かる.データが少ないこともあろう が, 伸縮計や傾斜計で観測された一連の異常変化と, 特 定の地域における地震活動の関係を取り扱った論文は少 ない.

§5. ま と め

地震予知研究計画の発足時には, 広域的な応力変化は 
測地測量で, 時間的な変化は地款変動連続観測で捕捉し ようとの考えがあった。この考えには広域的な応力に対 して地款が均一な変形をするとの前提があったと思われ る. しかし，我々が蓄積した資料から判断する限り，地 殼の変形は不均一で断層もしくは破砕帯は広域の応力の 影響を受けやすく，その近傍の観測点の方が前兆的な地 款変動を観測しやすい，このことは，地款を均一な弾性 体と考えるモデルでは前兆的変化に関する不十分な説明 しかできないことを意味している.

本稿では, 地殼の変形に際して流動や小破壊では変形 できない領域が形成されるとき，その形成に呼応して破 砕帯等で異常な変化が生じると推測した.このようなと きには条件さえよければ，その領域から遠方の観測点で あっても異常変化が観測できる. 現在の知識では 1 箇所 の観測点で異常な変化を観測したとしても，どの領域が 地震を発生するまでに成長するか特定することは難し い. けれども，データが蓄積して複数の観測点で異常が 観測されるようになれば，異常のパターンやそれが出現 する時間などから地震が発生する場所をある程度しぼり こめるようになろう，詳しい解析をするためには，観測 地点を増やしたり計器の開発を行って上質のデータを蓄 積し我々の知見を深めるよりない。

本稿を書くにあたっては多くの方々の観測されたデー タや論文を参考にさせていただいた。 また，これらの 方々や查読者から多くの貴重な助言をいただいた。この 紙面を借りて厚くお礼申しあげる。

\section{考文献}

檀原 毅, 1966, 松代地震に関連した地壳の上下変動, 測地学会誌, 12,18-45.

藤森邦夫・田部井隆雄・田中 豊, 1984，1984 年 5 月 30 日山崎断層地震前後の生野観測室における地殻変 動, 地震学会講演予稿集, No. 2, 9 .

笠原 稔， $1976 ， 1973$ 年根室半島沖地震の前兆的地款
変動, 地震予知シンポジゥム論文集 (地震学会), 314.

Miura, S., S. Nakao, T. Sato, K. Tachibana, M. MIShina, H. IshiI and A. TAKAgI, 1990, Pre- and postseismic crustal deformation associated with the 1983 Japan Sea earthquake, Sci. Rep. Tohoku Univ., Ser. 5, 33, 115-125.

Онуа, F., 1988, Crustal movements related to the earthquake on March 18, 1987 in Hyuganada, Bull. Disas. Prev. Res. Inst., Kyoto Univ., 38, 99-114.

小沢泉夫, 1978, 紀州鉱山における地款変動の観測一伸 縮計による観測一, 京大防災研究所年報, 21B, 113117.

佐藤春夫・立川真理子・大久保正, 1984 , 山梨県東部の 地震（1984 年 8 月 8 日）に先行した異常な地殻傾斜 変化, 地震 2, 37, 197-205.

竹本修三・高田理夫, 1969 , 地震に伴う strain step に ついて, 測地学会誌, 15, 68-74.

田中宙夫, 1972, 地球潮汐による傾斜, ひずみと海洋潮 汐について（第 1 報），測地学会誌，18，49-57.

田中 豊, 1965, 地震に伴う異常の諸段階について, 京 大防災研究所年報, 8, 91-108.

山内常生, 1981, 降雨に対する地款歪レスポンスのシ ミュレーション, 测地学会誌, 27, 40-49.

山内常生, 1985, 地款変動連続観測による地震予知, 測 地学会誌, 31, 59-72.

Yamauchi. T., 1987, Anomalous strain response to rainfall in relation to earthquake occurrence in the Tokai area, Japan, J. Phys. Earth, 35, 19-36.

山崎文人・大井田 徹, 1985 , 中部地方におけるフィ リッピン海プレート沈み込みの形状, 地震 $2,38,193-$ 201.

柳沢道夫, 1980, 宇佐美臨時観測点における降水量と傾 斜観測の関係, 測地学会誌, 26, 187-199.

WatANABE, K., 1991, Strain variation of the Yamasaki fault zone, southwest Japan, derived from extensometer observations, part 1 -On the longterm strain variations-, Bull. Disas. Prev. Res. Inst., Kyoto Univ., 41, 29-52. 